\title{
HAZAI FELSŐOKTATÁSI ÉS VÁLLALATI EGYÜTTMÜKÖDÉSEK AZ IPAR 4.0 SZEMPONTJÁBÓL
}

\author{
KISS ÉVA ${ }^{\mathrm{a}, *}$ - VARGA GYÖRGY \\ ${ }^{a}$ ELKH CSFK Földrajztudományi Intézet \\ ${ }^{\text {b} E L T E ~ T T K, ~ F o ̈ l d r a j z-e ́ s ~ F o ̈ l d t u d o m a ́ n y i ~ I n t e ́ z e t, ~}$ \\ Társadalom- és Gazdaságföldrajzi Tanszék
}

Beérkezett: 2021. május 27., elfogadva: 2021, október 24.

\begin{abstract}
A tanulmány azt tárja fel, hogy az iparban zajló forradalmi változásokra hogyan reagáltak a hazai felsőoktatási intézmények a kormányzati intézkedések és a vállalati együttműködések tükrében. A szakirodalmi forrásokra és az oktatási intézményi adatokra, valamint egy vállalati esettanulmányra alapozva megállapítható, hogy az elmúlt években jelentős előrelépés történt a felsőoktatási szakemberképzésben, hogy igazodjon az Ipar 4.0 kihívásaihoz. Ezt részben az állami szakpolitikák és főleg a német vállalatokkal folytatott együttmüködések elmélyülése tette lehetővé. Mindezek hosszabb távon a gazdasági és társadalmi következmények mellett a magyar ipar területi folyamataira is hatással lehetnek.
\end{abstract}

Kulcsszavakः Ipar 4.0, felsőoktatás, vállalati együttmüködés, mechatronikai mérnökképzés, duális képzés

This paper investigates how Hungarian higher education institutions have responded to revolutionary changes in industry reflecting government measures and corporate partnerships. Based on the literature and educational institutional data, as well as a company case study, it can be concluded that in recent years significant progress has been made in the training of professionals in higher education in order to be adjusted to the challenges of Industry 4.0. This was made partly possible by the deepening of state policies and, in particular, cooperation with German companies. In the long term, all these can have an impact on the spatial processes of the Hungarian industry, in addition to economic and social consequences.

Keywords: Industry 4.0, higher education, corporate partnership, mechatronics engineer training, dual training

\footnotetext{
* Levelező szerző: Dr. Kiss Éva, ELKH CSFK Földrajztudományi Intézet, 1112 Budapest, Budaörsi út 45. E-mail: kiss.eva@csfk.org, kisse@helka.iif.hu
} 


\section{Bevezetés}

$\mathrm{A}$ z utóbbi években egyre gyakrabban hangzik el az a megállapítás, hogy napjainkban már a negyedik ipari forradalom, vagy másképp az Ipar 4.0 korát éljük. Jóllehet ezeknek a fogalmaknak egyelöre nincs egységesen elfogadott definíciójuk (Fonseca 2018; Kiss-Nedelka, 2020; Schwab 2016). Ami bizonyos, hogy az Ipar 4.0 kifejezés először 2011-ben a német ipar stratégiai fejlesztési programjában jelent meg, akkor még Industrie 4.0 néven (Bartodziej 2017). Szükebb értelemben azokat az új technológiákat jelenti, amelyek forradalmasítják az ipari termelést. Az automatizáció, a digitalizáció és a robotizáció fokozódásával radikális változások következnek be nemcsak a különböző termelési és értékesítési láncokban, illetve a gazdaság egészében, hanem az élet minden területén. Ezek azonban térben és időben differenciáltan zajlanak, és számos tényező befolyásolja (pl. vállalkozások felkészültsége, infrastruktúra fejlettsége, munkaerő képzettsége). Több kutatás is arra a következtetésre jutott, hogy az új technológiák terjedésének, különösen a kisebb vállalkozások esetében az egyik legfőbb korlátozó tényezője a megfelelően képzett munkaerő hiánya (Kopp-Basl 2017; Nagy-Molnár-Kiss 2020; Sommer 2015). Éppen ezért egyrészt felértékelődik a vállalatok és a különböző oktatási intézmények közötti együttműködés jelentősége a képzésben. Másrészt pedig szükségessé válik a felsőfokú képzés igazítása is az újabb ipari forradalom kihívásaihoz. Mindebből kiindulva tanulmányunkban arra keressük a választ, hogy az Ipar 4.0-val összefüggésben milyen változások következtek be az ipari vállalatok és felsőoktatási intézmények együttműködéseiben.

A tanulmányban először a hozzáférhető oktatási, képzési adatbázisok (pl. Oktatási Hivatal, Felvi.hu) felhasználásával azt mutatjuk be, hogy miként valósul meg az ipari vállalatok és a felsőoktatás közötti együttmüködés az Ipar 4.0 szempontjából, megkülönböztetett figyelmet fordítva a mechatronikai mérnökképzésre, mint az újabb ipari forradalom egyfajta indikátorára. Majd esettanulmány jelleggel egy, az Ipar 4.0 technológiák alkalmazásában élenjáró többtelephelyes nagyvállalat (Continental) példáján keresztül a gyáregységek és az egyetemek között megvalósuló együttműködések főbb sajátosságait tárjuk fel a negyedik ipari forradalom korában.

\section{A mechatronikai mérnökképzés mint az Ipar 4.0 indikátora}

Ideális esetben a felsőoktatási intézmények képzései követik a munkaerőpiaci igényeket. Ebből kiindulva azt vizsgáltuk, hogy egy jelentős technológiai változással jellemezhető korszakban a hazai felsőoktatási intézmények hogyan reagálnak az új igényekre. A kérdés megválaszolásához tanulmányoztuk az egyes egyetemek által meghirdetett szakok leírását, hogy közülük melyek lehetnek azok, amelyeket az új idők hívtak életre. A Felvi.hu-n található számos képzés ismertetőjének értékelése után a mechatronikai mérnöki szak (alap-és mesterképzés egyaránt) tủnt a leginkább megfelelőnek arra, hogy a hazai felsőoktatási intézmények negyedik ipari forradalomra adott egyfajta reakciójaként kezeljük.

Elöljáróban érdemes megnézni, hogy pontosan mi is a mechatronikai mérnöki szakképzés célja. Alapképzésen olyan "mechatronikai mérnökök képzése, akik alkalmasak a gépészetet az elektronikával, elektrotechnikával és számítógépes irányítással 
szinergikusan integrálni, képesek mechatronikai berendezések és folyamatok, továbbá intelligens gépek rutinszerű tervezési feladataira, üzemeltetésére és fenntartására, mechatronikai technológiák bevezetésére, alkalmazására, folyamat- és termelésirányítás energiahatékony és környezettudatos megszervezésére, a műszaki fejlesztés és tervezés átlagos bonyolultságú feladatainak ellátására a nemzetközi munkaerőpiac igényeit is figyelembe véve” (Felvi.hu 2020a). Mesterképzésen pedig olyan „mechatronikai mérnökök képzése, akik képesek világszínvonalon a gépészetet az elektronikával, elektrotechnikával és számítógépes irányítással szinergikusan integrálni, alkalmasak mechatronikai berendezések, folyamatok és rendszerek, valamint intelligens gépek koncepciójának kidolgozására, modellezésére, majd tervezésére, gyártástervezésére, valamint üzemeltetésére és karbantartására. Képesek mechatronikai rendszerekhez szükséges új technológiák, eljárások, anyagok kifejlesztésére, bevezetésére; magasabb szintű vezetési, irányítási és szervezési feladatok ellátására; a müszaki fejlesztés, kutatás, tervezés és innováció feladatainak ellátására; hazai, és nemzetközi szintű mérnöki projektekhez való kapcsolódásra, azok irányítására." (Felvi.bu 2020b.) A BSc- és MScképzés leírásából is jól érzékelhető, hogy ezek számottevő Ipar 4.0 relevanciával bírnak.

A mechatronikai mérnökképzés életre hívását az sürgette, hogy a 20. század második felében az informatika gyors fejlődésnek indult, a mesterséges intelligencia hordozója az elektronika lett. Az elektronikus és informatikai elemek pedig elkezdtek beépülni az addig tisztán gépészeti rendszerekbe és az 1980-as, 1990-es évekre már az olyan optimalizált rendszerek voltak a jellemzők, amelyeket nem lehetett mechanikai, elektronikus vagy informatikai egységekre szétszedni (BME 2008). A mechatronikai mérnökök tehát ötvözve a gépész-, a villamosmérnöki és az informatikai ismereteket fontos szerepet játszhatnak a negyedik ipari forradalom új technikáinak és technológi-

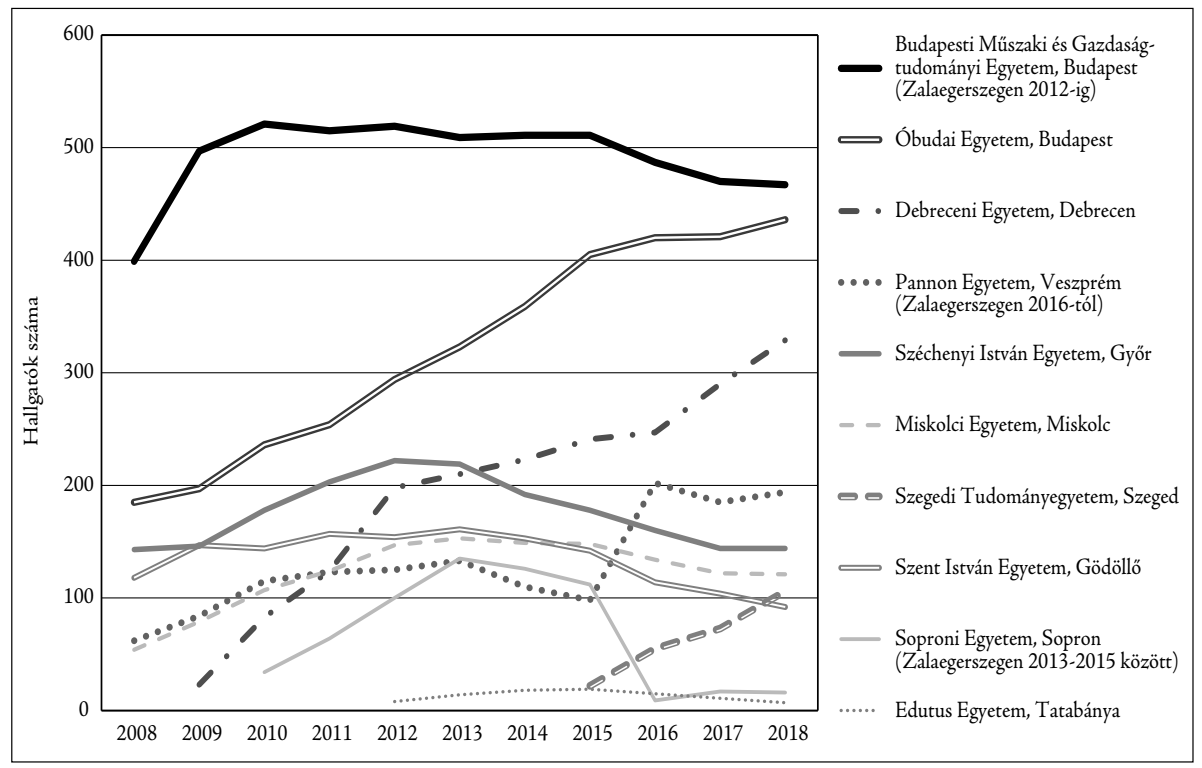

1. ábra: A mechatronikai mérnöki alapképzésben tanuló nappali tagozatos hallgatók száma (fö) egyetemenként, 2008-2018. Forrás: Oktatási Hivatal 
áinak az eloállításában, azaz az Ipar 4.0 gyakorlati megvalósításában. Külföldön jóval hosszabb múltra tekint vissza a mechatronikai mérnökképzés, amit az is bizonyít, hogy Észtországban már az 1980-as években, Németországban és Új-Zélandon pedig már az 1990-es évek elején megjelent (Grimbeden-Hanson 2005).

Magyarországon 2008-tól állnak rendelkezésre adatok a mechatronikai mérnök szakon tanulók számáról. Akkor hat egyetem alapképzésén összesen 961-en tanultak, 61\%-uk fóvárosi karokon. A későbbiekben folyamatosan nőtt az ilyen szakos hallgatók száma, miközben a felsőfokú intézményekben tanulóké csökkent. Az előbbihez az is nagyban hozzájárult, hogy a képzőhelyek száma tíz lett, és hogy nőtt a munkaerőpiaci kereslet a végzettek iránt. 2018-ban már 1900-nál is többen voltak alapszakos mechatronikai mérnökhallgatók. Az viszont, hogy a számuk nem változott drasztikusan az elmúlt évtizedben - tartósan 1800-1900 fö körül volt minden évben -, arra utal, hogy stabil az érdeklődés a képzés iránt. Összefügghet ez azzal is, hogy ez az időszak egyben a negyedik ipari forradalom kibontakozásának is az ideje, amikor fokozódott az igény a mechatronikát végzettek iránt (1. ábra).

A mechatronikai mérnöki alapképzésben részt vevő hallgatók döntő többsége Budapesten (Budapesti Müszaki és Gazdaságtudományi Egyetem, Óbudai Egyetem) és agglomerációjában (gödöllői Szent István Egyetem) tanul. Az, hogy 2008 és 2018 között összességében mégis csökkent a fóvárosi régió súlya (73\%-ról 52\%-ra), leginkább abból fakadhat, hogy az ország más részeiben több lett a mechatronikai mérnökhallgató. A leglátványosabban az alföldi oktatási centrumokban (2009-től Debrecenben és 2015től Szegeden) nőtt a számuk, ahol a felsőfokú müszaki szakemberképzés és a gépipar is szerényebb hagyományokkal rendelkezett, különösen igaz ez a Tisza-parti városra. 2014-ben a fóvároson kívül már a Debreceni Egyetemen volt a legmagasabb a mechatronikai mérnöki alapképzésen tanulók száma (223fö), ami mintegy tízszeres növekedés a kezdetekhez képest. Ez elsősorban annak a következménye, hogy olyan új ipari (főként jármüipari) beruházásokat jelentettek be Debrecenben néhány éve, amelyekhez szakképzett munkaerőre lesz szükség (Molnár-Kozma 2019).

Az elmúlt évtizedben a mesterképzést nyújtó intézmények száma is bővült. Amíg 2008-ban a mechatronikai mérnöki MSc-képzés csak a Budapesti Müszaki és Gazdaságtudományi Egyetemen (továbbiakban BME) és a győri Széchenyi István Egyetemen folyt, addig tíz évvel később már további négy intézményben, de a mesterképzésben tanulók száma így is elmarad az alapképzésekétől. Ez mindenekelőtt annak tudható be, hogy a kisebb egyetemeken (pl. Soproni Egyetem, Edutus Egyetem) nehezen biztosíthatók a mechatronikai mérnöki MSc-képzés feltételei. Arról nem is beszélve, hogy a relatíve kevés BSc-s hallgatóból valószínüleg kevesebben is szándékoznak mesterképzésre menni (2. ábra).

Általában a BSc-t végzett mechatronikai mérnökök alacsony továbbtanulási hajlandósága arra vezethető vissza, hogy a munkaerőpiaci lehetőségek igen kedvezőek az elhelyezkedésre már az alapképzés után is. Ezért is jóval kisebb (kb. egyhatoda) a mesterképzésen tanulók száma az alapképzésen tanulókéhoz viszonyítva. 2012 és 2018 között 178-271 fö tanult mechatronikai MSc-n, túlnyomórészük Budapesten. 2009től kezdve a BME-n mindig többen tanultak mechatronikai mesterképzésen, mint az ország összes többi képzőintézményében együttvéve. A vidéki egyetemek közül a Debreceni Egyetem emelhető ki, amely a BME mögött a második legjelentősebb oktatási intézmény az országban a mechatronikai mérnöki mesterképzés terén. Hallgatóinak 


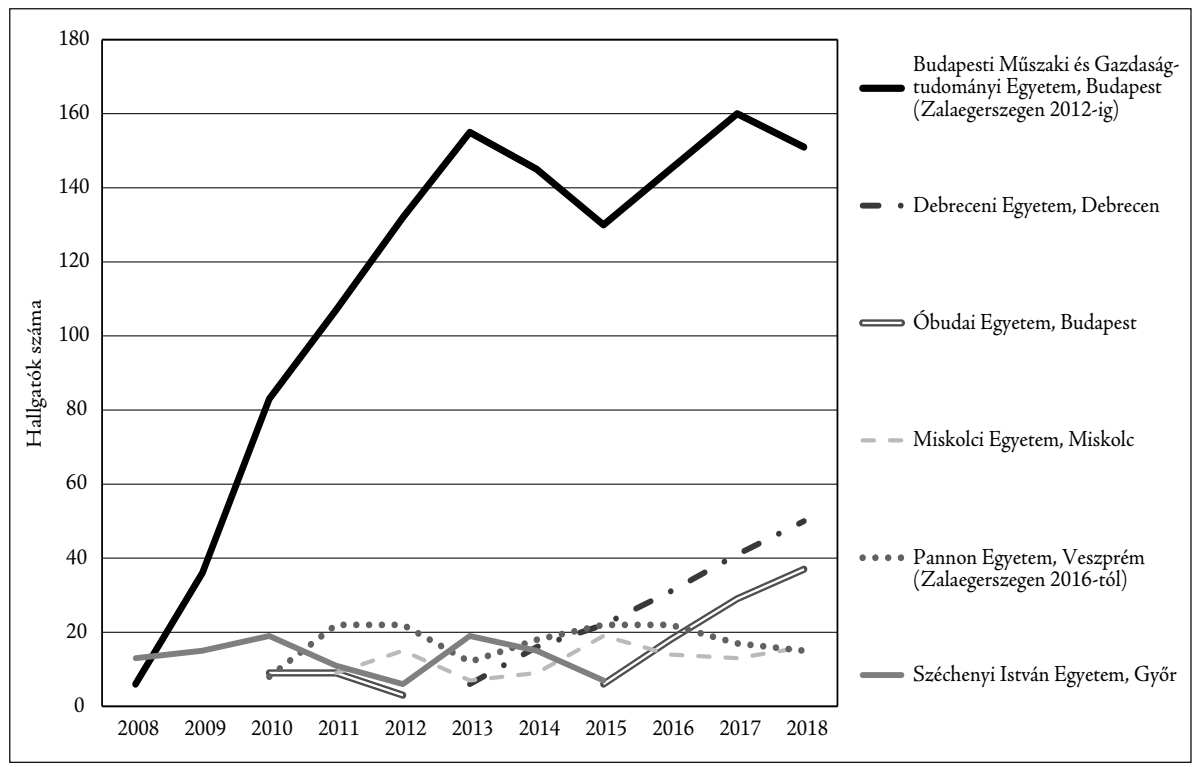

2. ábra: A mechatronikai mérnöki mesterképzésben tanuló nappali tagozatos hallgatók száma (fö) egyetemenként, 2008-2018. Forrás: Oktatási Hivatal

száma 2013-tól, a képzés indításától kezdve dinamikusan gyarapodott és 2018-ban már elérte az 50 föt, de ez még így is csak harmada a BME hallgatóinak. Az utóbbi években a hallgatói létszám emelkedéséhez az is hozzájárult, hogy a nagymúltú német autógyár, a BMW a városban létesít autógyárat (Molnár et al. 2020). A debreceni értékekkel szemben a többi vidéki (győri, miskolci, veszprémi) egyetemen igen kevés (2-16 fö) volt a mesterképzéses mechatronikai mérnökhallgató. A győri Széchenyi István Egyetemen alig akad mechatronikai mérnöki mesterképzésben tanuló hallgató, ami minden bizonynyal a jó helyi munkalehetőségeknek köszönhető, valamint annak, hogy a munkáltatók igyekeznek már az alapképzés után beintegrálni a hallgatókat a munkába.

Idehaza alapszakon és mesterszakon is közel 50 képzés végezhető duális formában, amiben 2019-ben 553 partnerszervezet közremüködésével 2285 hallgató vett részt, 92\%-uk alapszakosként (Vida 2021). Mindezen hallgatói adatokból a duális képzés csekély népszerűsége sejthető. A mechatronikai mérnöki szakképzést is lehet duális képzési formában végezni. A duális mechatronikai képzést 2020-ban alapszakon hat egyetemen 82 partnerszervezettel együttmüködve, mesterszakon pedig négy egyetemen összesen 31 partnerszervezettel együttmüködve hirdették meg. A legtöbb partnerszervezettel, ami alapszakon 33, mesterszakon 11 céget jelent a veszprémi székhelyü és zalaegerszegi telephellyel is rendelkező Pannon Egyetem müködik együtt. Szintén nagyon széles (27 tagú) az alapszaki partnerhálózata a Szegedi Tudományegyetemnek. A Miskolci Egyetemen viszonylag kiegyensúlyozott a partnerek száma: alapszakon 13, mesterszakon 11, míg az Óbudai Egyetemen 4, illetve 6. A soproni és a tatabányai egyetemen csak alapképzés van 2-3 vállalat részvételével.

Arra vonatkozóan, hogy az egyes partnervállalatok által folytatott képzés mennyire kapcsolódik az Ipar 4.0-hoz vagy, hogy mennyire Ipar 4.0 érettek ezek a cégek, nincse- 
nek megbízható információk. Ellenben jelzésértékű lehet az, hogy az Ipar 4.0 Nemzeti Technológiai Platform tagjai közül csak három folytat együttműködést felsőoktatási intézménnyel mechatronikai mérnöki duális képzés terén: egy a Miskolci Egyetemmel, kettő pedig a Pannon Egyetemmel. A mechatronikai mérnöki képzésen kívül is csak 11 olyan, jobbára nagynevü német vállalat van (pl. Robert Bosch Kft., Siemens Zrt., ZF Hungária $\mathrm{Kft}$.), amelyek részt vesznek valamilyen más (döntően mérnöki) duális képzésben. S mivel az Ipar 4.0 koncepciója és a hazai duális képzés rendszere is német gyökerekkel rendelkezik, ezért nagyon valószínű, hogy ezek a vállalatok előrébb járnak az újabb technológiai vívmányok alkalmazásában, ami a képzésük színvonalában és a hallgatók tudásában is megnyilvánulhat.

\section{Egy német multinacionális nagyvállalat felsőoktatási együttmüködése}

Magyarországon az ipari vállalatok és az egyetemek közötti szorosabb együttmúködés lényegében az ezredforduló utáni években kezdődött és a 2008-as válságból való kilábalást követően vált intenzívebbé. $\mathrm{Az}$, hogy ebben a német vállalatok úttörő szerepet játszottak, nem véletlen. Hiszen a magyar gazdaságban és föleg a magyar iparban számottevő a német tőkebefektetés és a német tulajdonban levő vállalatok száma. A rendszerváltozás kezdetétől fogva a hazánkba érkező külföldi tőke tekintélyes hányadát tették ki a német befektetések, amelyek mindenekelőtt a jármüiparba és az elektronikai iparba irányultak (Kiss 2007; Vápár 2013). Ráadásul ez a két ágazat az ipar meghatározó szegmense is, mivel az ipari termelés értékének tekintélyes hányadát (2019-ben 29, illetve $12 \%$-át) teszik ki. De azért is fontos a vizsgálatuk, mert ezek azok az ágazatok, ahol az Ipar 4.0 a legelőrehaladottabb (Losonci-Takács-Demeter 2019). Ugyanakkor egyre nagyobb nehézség a megfelelő számú és képzettségű munkaerő biztosítása a vállalatok számára. Fontos kiemelni azt is, hogy Németországban már több évtizedes hagyománya van az ipari cégek és a felsőoktatási intézmények együttmüködésének (Euler 2013). A „stuttgarti modell” alapja, hogy a felsőoktatásban tanuló hallgatók az elméleti ismereteket a felsőoktatási intézményben, míg a gyakorlati tudnivalókat az üzemekben sajátítsák el.

A német Continental multinacionális nagyvállalat az elmúlt évtizedekben folyamatosan terjeszkedett Magyarországon részben felvásárlás, részben zöldmezős beruházás révén. Napjainkban már hét gyárral (Budapest, Veszprém, Szeged, Makó, Vác, Nyíregyháza, Debrecen), egy gumiabroncs kereskedelmi egységgel (a kirendeltség Budaörsön, a raktár Mosonmagyaróváron van) és egy mesterséges intelligenciafejlesztő központtal (Budapest) képviselteti magát. A vállalatcsoport nemcsak jelentős foglalkoztató, mivel több ezer főnek (2020-ban mintegy nyolcezernek) ad munkát, hanem az ipari innovációk fejlesztésében és alkalmazásában is élen jár hazánkban.

A vállalat hét telephelyének településein 2020 júliusa és októbere között összesen kilenc interjú készült részben a vállalatcsoport két vezető beosztású munkavállalójával, részben két felsőoktatási szakemberrel, valamint öt, a helyi gazdaságfejlesztésben érdekelt szakemberrel (pl. ipari park ügyvezető, iparkamara képviselö, önkormányzati munkatárs). Ezek és a vállalattal kapcsolatban online megjelent sajtóanyagok alapján elmondható, hogy a szükséges számú és minőségű munkaerő biztosítása a Continental hazai telephelyei számára is komoly kihívás, ezért is fontos a felsőfokú intézményekkel való együttműködés. A munkaerőpótlás mértéke erősen függ az egyes telephelyek 
lokális társadalmi, gazdasági adottságaitól is. Leginkább a magasan kvalifikált munkaerővel való ellátottság ütközik nehézségekbe, habár a budapesti telephelyen ennek éppen az ellenkezője tapasztalható. A budapesti Ipar 4.0 mintagyár a szellemi munkaerő (döntően mérnök) utánpótlását elsősorban a tehetségek korai bevonzására alapozza. Gyakornoki programjukba évente 70-80 mérnökhallgatót vonnak be, akiket egyetemi tanulmányaik elvégzését követően általában fel is vesznek a vállalathoz mérnöki munkakörbe. Átlagosan tízből hat mérnököt pályakezdőként vagy kevés munkatapasztalattal alkalmaznak. A későbbi előrelépésükben azonban meghatározó szerepe van a vállalat saját fejlesztési programjainak. Így akár belső forrásból is ki tudják elégíteni a közép- és felsővezetői munkaerö-szükségletüket (pl. van korábbi gyakornokukból lett gyáregység-igazgatójuk is) (Barna 2019). Az iparvállalat szintén a szellemi foglalkozású munkaerő utánpótlása érdekében kötött együttműködési megállapodást a BME-vel néhány nappal azelőtt, hogy bejelentette, hogy Budapesten mesterséges intelligenciafejlesztő központot fog nyitni (Continental.com 2018).

A debreceni Continental-beruházásnak is az egyik kardinális kérdése volt a szakember-utánpótlás, amit ugyancsak az ottani felsőoktatási intézménnyel a gyár alapkőletétele után, a 2019 elején megkötött stratégiai együttműködési megállapodás révén kívántak megoldani. A Continental helyi gyára (ami 2019 őszétől a Vitesco Technologies Hungary Kft. nevet viseli) és a Debreceni Egyetem közötti kooperáció egyik legszembetűnőbb példája az, hogy a Müszaki Karnak a mechatronikai mérnöki mesterképzési szakán jármümechatronikai szereléstechnológia (azaz „Vitesco”) szakirány indult a

1. táblázat: A Continental gyáregységek és felsőoktatási intézmények együttműködései a duális képzés terén, 2020

\begin{tabular}{|c|c|c|c|}
\hline $\begin{array}{l}\text { Continental } \\
\text { gyáregység neve } \\
\text { (telephelye) }\end{array}$ & $\begin{array}{l}\text { Felsőoktatási } \\
\text { intézmény }\end{array}$ & Alapképzés & Mesterképzés \\
\hline \multirow[t]{2}{*}{$\begin{array}{l}\text { ContiTech Rubber } \\
\text { Industrial Kft. } \\
\text { (Szeged) }\end{array}$} & $\begin{array}{l}\text { Szegedi } \\
\text { Tudományegyetem }\end{array}$ & $\begin{array}{l}\text { - gépészmérnöki } \\
\text { - müszaki menedzser } \\
\text { - mechatronikai } \\
\text { mérnöki }\end{array}$ & $\begin{array}{l}\text { - gépészmérnöki } \\
\text { - mechatronikai } \\
\text { mérnöki } \\
\text { - pénzügy }\end{array}$ \\
\hline & Óbudai Egyetem & $\begin{array}{l}\text { - gépészmérnöki } \\
\text { - mechatronikai } \\
\text { mérnöki }\end{array}$ & \\
\hline \multirow[t]{2}{*}{$\begin{array}{l}\text { ContiTech Fluid } \\
\text { Automotive Hungária } \\
\text { Kft. (Makó, Vác) }\end{array}$} & $\begin{array}{l}\text { Szegedi } \\
\text { Tudományegyetem }\end{array}$ & $\begin{array}{l}\text { - gépészmérnöki } \\
\text { - müszaki menedzser } \\
\text { - mechatronikai } \\
\text { mérnöki }\end{array}$ & - gépészmérnöki \\
\hline & $\begin{array}{l}\text { Szent István } \\
\text { Egyetem }\end{array}$ & - gépészmérnöki & \\
\hline \multirow{2}{*}{$\begin{array}{l}\text { ContiTech } \\
\text { Magyarország Kft. } \\
\text { (Nyíregyháza) }\end{array}$} & Debreceni Egyetem & - gépészmérnöki & \\
\hline & $\begin{array}{l}\text { Nyíregyházi } \\
\text { Egyetem }\end{array}$ & - gépészmérnöki & \\
\hline
\end{tabular}

Forrás: Felvi.hu 
2019/2020-as tanévben. A végzett hallgatók pedig a 2021-ben termelni kezdett, Ipar 4.0 gyártási eljárásokkal is rendelkező helyi „Vitesco” gyárban helyezkedhetnek el (Rituper 2020). Érdemes megjegyezni, hogy ez a szakirányindítás nem volt előzmény nélküli Magyarországon, mivel 2010-től a Pannon Egyetemen „Continental” jármürendszertechnikai mérnöki mesterképzés indult a mechatronikai mérnökképzésen belül. A Continental és a Pannon Egyetem közötti együttmüködés egyébként nagy múltra tekint vissza, amiről a szerződést még 2001-ben írták alá (Pannon Egyetem 2010).

A Continental a duális képzésben is részt vesz. Néhány gyáregysége több hazai felsőoktatási intézménnyel is együttmüködik, föleg az alapképzésben (1. táblázat).

A Continental duális képzésben való részvétele elsődlegesen a hagyományosabb müszaki-gépészmérnöki szakemberképzéshez kapcsolódik, ami arra utalhat, hogy ezeknek a telephelyeknek az Ipar 4.0 érettségi szintje is szerényebb mértéket ölt. Összefügghet ez azzal is, hogy a Continental ezen egységeiben olyan ipari, gumiipari tevékenységet folytatnak, amelyekben az új technológiák kevésbé alkalmazhatók. Ugyanakkor, ahol jármüipari, illetve elektronikai termékeket állítanak elő, ott elterjedtebb az új technológiák használata, vagyis előrehaladottabb az Ipar 4.0 kiteljesedése.

\section{Összefoglalás}

Az elmúlt évtizedben az Ipar 4.0 új technológiáinak köszönhetően az iparban zajló forradalmi változásokra a szakember-utánpótlás érdekében az állami szakpolitikák és azokkal összhangban a felsőoktatási intézmények is igyekeztek reagálni. Tanulmányunkban az ipari vállalatok és felsőoktatási intézmények együttműködésének vizsgálatát helyeztük a középpontba. Megállapítottuk, hogy a felsőoktatási intézmények képzési struktúrájukat térségük iparvállalataival együttmüködve igyekeznek azok igényeinek megfelelően alakítani. S ez a törekvés az utóbbi évtizedben egyre határozottabban érvényesül. Ugyanakkor az is nyilvánvalóvá vált, hogy a felsőoktatási intézmények képzési struktúráját is alapvetően a nagyvállalatok képesek érdemben befolyásolni. Különösen kezdetben a német vállalatok játszottak úttörő szerepet a kooperáció generálásában, mivel Németországban, elsősorban a szakemberképzés és utánpótlás céljából nagy hagyományai vannak a vállalati és képzési együttműködéseknek. De azért is fontosak a német vállalatok, mert a negyedik ipari forradalom „bölcsőjének” is tekinthetők, hiszen élen járnak az új technológiák alkalmazásában, amelyek azután az ott folyó oktatásban, szakképzésben is megjelenhetnek és számottevően formálhatják azt. Tapasztalható ez az Ipar 4.0 szempontjából releváns ismereteket közvetítő mechatronikai mérnökképzésben és a több telephelyes német nagyvállalat, a Continental gyáregységei és a helyi felsőfokú intézmények kapcsolatában is.

$\mathrm{A} z$, hogy a Continental több telephelye a helyi vagy közeli egyetemmel müködik együtt, azért is kedvező, mert így lehetőség van az ottani helyi, térségi igényekhez való jobb illeszkedésre, a digitalizációra és a technikai modernizációra, amelyek fontos feltételei a duális képzés eredményességének (Poór-Zsigri-Sós 2019). Különösen kedvező kihatása lehet az egyetemek és a vállalatok kooperációjának a periférikus térségek gazdasági, társadalmi fejlődésében (Gál 2016). Összességében tehát a képzési struktúrának a negyedik ipari forradalom kihívásaihoz való igazítása, valamint az oktatási intézmények erősödő vállalati együttműködése nemcsak a munkaerőpiacra, a szakemberutánpótlásra hat előnyösen, hanem szélesebb társadalmi, gazdasági konzekvenciákkal 
is együtt járhat. Miközben az alföldi egyetemi központokban a műszaki képzés jelentősebbé válásával párhuzamosan a hazai ipar térszerkezetében is releváns változások következhetnek be.

\section{Köszönetnyilvánítás}

A tanulmány az NKFIH által támogatott K125091 sz. projekt keretében készült. A támogatásért ezúton is köszönetüket fejezik ki a szerzők.

\section{IRODALOM}

BARNa E. (2019) 100-ból 98 embert már nem az utcáról veszünk fel. https://www.hrportal. $\mathrm{hu} / \mathrm{hr} / 100$-bol-98-embert-mar-nem-az-utcarol-veszunk-fel-20191028.html [Letöltve: 2020. 10. 06.]

Bartodziej, C. J. (2017) The Concept Industry 4.0. An Empirical Analysis of Technologies and Applications in Production Logistics. Berlin, Springer Gabler.

BME (2008) Útmutató a mechatronikai mérnöki alapszak (BSc) hallgatói részére a 2008/2009, tanévre. https://gpk.bme.hu/downloads/hu/dokumentumok/Archivum/ Mechatronikai-mernoki-alapszak-ZE-2008.pdf [Letöltve: 2021. 01. 01.]

Continental.сом (2018) A Continental mesterséges intelligencia központot nyit Budapesten. https://www.continental.com/hu-hu/sajto/sajt\%C3\%B3koezlem\%C3\%A9 nyek/a-continental-mesters\%C3\%A9ges-intelligencia-koezpontot-nyit-budapesten120120 [Letöltve: 2020. 03.31.]

Euler, D. (2013) Germany's Dual Vocational Training System: A Model for Other Countries? Gütersloh, Bertelsmann-Stiftung.

Felvi.Hu (2020a) Mechatronikai mérnöki alapképzési szak. https://www.felvi.hu/felveteli/ szakok_kepzesek/szakleirasok/!Szakleirasok/index.php/szak/62/szakleiras [Letöltve: 2021. 01. 01.]

Felvi.hu (2020b) Mechatronikai mérnöki mesterképzési szak. https://www.felvi.hu/felveteli/ szakok_kepzesek/szakleirasok/!Szakleirasok/index.php/szak/278/szakleiras [Letöltve: 2021. 01. 01.]

Fonseca, L. M. (2018) Industry 4.0 and the Digital Society: Concepts, Dimensions and Envisioned Benefits. Proceedings of the 12th International Conference on Business Excellence. DOI: 10.2478/pichbe-2018-0034.

GÁl Z. (2016) Egyetem és város. Educatio, Vol. 25. No. 2. pp. 220-233.

Grimheden, M. \& Hanson, M. (2005) Mechatronics - The Evolution of an Academic Discipline in Engineering Education. Mechatronics, Vol.60. No. 15. pp. 179-192. DOI: 10.1016/j.mechatronics.2004.07.010

KIss, E. (2007) Foreign Direct Investment in Hungary: Industry and Its Spatial Effects. Eastern European Economics, Vol. 45. No. 1. pp. 6-28.

Kiss É. \& Nedelka E. (2020) Geographical Approach of Industry 4.0 Based on Information and Communication Technologies at Hungarian Enterprises in Connection with Industrial Space. Hungarian Geographical Bulletin, Vol. 69. No. 2. pp. 99-117.

Kopp, J. \& BASL, J. (2017) Study of the Readiness of Czech Companies to the Industry 4.0. Journal of Systems Integration, Vol. 4. No. 3. pp. 40-45. 
Losonci D., Takács O. \& Demeter K. (2019) Az ipar 4.0 hatásainak nyomában - a magyarországi járműipar elemzése. Közgazdasági Szemle, Vol. 66. No. 2. pp. 185-218.

Molnár E. \& Kozma G. (2019) A debreceni gazdaságfejlesztés zászlóshajói: a városban müködő ipari parkok jellegzetességei. Tér és Társadalom, Vol. 33. No. 3. pp. 49-71.

Molnár E., Kozma G., Mészáros M. \& Kiss É. (2020) Upgrading and the Geography of the Hungarian Automotive Industry in the Context of the Fourth Industrial Revolution. Hungarian Geographical Bulletin, Vol. 69. No. 2.pp. 137-155. DOI: 10.15201/ hungeobull.69.2.4

Nagy Cs., Molnár E. \& Kiss É. (2020) Industry 4.0 in a Dualistic Manufacturing Sector - Qualitative Experiences from Enterprises and Their Environment, Eastern Hungary. Hungarian Geographical Bulletin, Vol. 69. No. 2. pp. 157-174.

Pannon Egyetem (2010) Jármürendszertechnikai képzés indul. https://doksi.net/hu/news. php?order=ShowArticle\&id=1454 [Letöltve: 2021.01 .03 .]

Poór J., Zsigri F. \& Sós T. (2019) A német minta és a hazai gyakorlat a felsőoktatási duális képzés területén. Munkaügyi Szemle, Vol. 62. No. 6. pp. 41-53.

Rituper T. (2020) Már kétszáz munkatárs dolgozik az elektromobilitás jövöjén a Vitesco Technologies debreceni üzemében. https://www.dehir.hu/debrecen/mar-ketszazmunkatars-dolgozik-az-elektromobilitas-jovojen-a-vitesco-technologies-debreceniuzemeben/2020/11/26/ [Letöltve: 2020. 01. 03.]

Sommer, L. (2015) Industrial Revolution-industry 4.0: Are German Manufacturing Smes the First Victims of this Revolution? Journal of Industrial Engineering and Management, Vol. 8. No. 5. pp. 1512-1532.

Schwaв, K. (2016) The Fourth Industrial Revolution. World Economic Forum, Cologne/ Geneva. Available at https://www.weforum.org/about/the-fourth-industrial-revolutionby-klaus-schwab

VÁpÁr J. (2013) A német müködőtőke-befektetések Magyarországon. Tér és Társadalom, Vol. 27. No. 1. pp. 129-144.

VIDA C. (2021) Felsőoktatás a változások tükrében - verseny, minőség, teljesítmény. Budapest, Állami Számvevőszék.

A cikk a Creative Commons Attribution 4.0 International License (https://creativecommons.org/licenses/bync/4.0/) feltételei szerint publikált Open Access közlemény, melynek szellemében a cikk bármilyen médiumban szabadon felhasználható, megosztható és újraközölhető, feltéve, hogy az eredeti szerző és a közlés helye, illetve a CC License linkje és az esetlegesen végrehajtott módosítások feltüntetésre kerülnek. 